DOI: $10.20472 /$ IAC.2017.029.031

\author{
MARIA ANNA TUROSZ \\ Lomza State University of Applied Science, Poland
}

ANNA BROJEK

Lomza State University of Applied Science, Poland

KRZYSZTOF SYCHOWICZ

Lomza State University of Applied Science, Poland

\title{
THE MEANING OF PERSONALITIES FACTORS IN A PROCESS OF ACADEMY STUDENTS ADAPTATION.
}

\begin{abstract}
:
The aim of researches was to define the meaning of personality variables in optimization of adaptation process to young people studies who have just started studies at Academies. The researches were run at Lomza State University of Applied Science in Poland. 313 students of the 1st year took part in the research. They were students of 12 fields of studies. In the researches surveys with 24 questions were used. Thanks to that 3 levels of adaptation were defined- weak, partly and full. Personalities variables were describes by using 4 psychological questionnaire which enable to define the following levels:

-satisfaction of life (SWLS by E. Diener, R. A. Emmons, R. J. Larson, S. Griffin),

-self-assessment (SES by M.Rosenberg),

-emotional intelligence (PKIE by A.Jaworowska, A.Matczak),

-social expertise (PROKOS by A.Matczak, K.Martowska).

The Cronbach Ralpha reliability of scales were $\alpha=.81$ do $\alpha=.95$. TThe data obtained from the scales were analysed by using the SPSS 21.0. In order to determine differences Kruskal-Wallis $\mathrm{H}$ Test using SPSS Statistics the grade, a one-way variance analysis (ANOVA) were used. $\mathrm{QThe}$ fully social- educational adaptation of 1st year students foster high level of life quality, self-assessment, social expertise (mainly: assertiveness, conviviality, social activist). Academy should actively support students who start their studies by organising during the 1st semester additional adaptation workshops and inspire people and students to social actions which help to be a part of local society life.
\end{abstract}

\section{Keywords:}

personality, adaptation, students 


\section{Introduction}

The issue of adaptation to higher education is a subject of many interdisciplinary research, analysis and discussion. As psychological, economical and social phenomenon is in the centre of attention in educational authority as well as in employees of higher education (Iskra, 2011).

The aim of this article is to term personal conditioning in adaptation process among first year students of Lomza State University of Applied Sciences.

Current world is for a lot of young people the world of changes and opportunities. The pass to function efficiently in dynamically changing third millennium civilization is science and knowledge. Information is a key to human development process.

Young people are aware that education is their chance to realize their plans, dreams, missions and visions. They are taking up the gauntlet when they decide to go to the university. The beginning of learning is a turning point in young human life.

The time when they becoming students for the first time in their life is especially hard. First year of studies is series of social, economical and demographic changes in their lifetime. It is difficult time to develop and shape personality, identity and individual world view.

Leaving family house and place of residence, changes in social relations as well in routine and lifestyle. What is the most important for first year students is process of adaptation to the university requirements.

Adaptation as individual ability, psycho-behavioral function seems to be the response from our organism to new, difficult circumstances, conditions and situations (Martin et al., 2012). The whole process of adaptation is multidimensional and complicated.

There is no doubt that especially difficult situation is the difference between high school and requirements at the university. University is a place with a new structure. We can notice that there are different requirements, laws, duties and organisation system. The way to teach, to learn, forms and methods that are used in didactic educational work are diametrical different than the requirements that we used to know in high school. Equally important is the new social environment as well as in the form of academic teacher and new group of age-mates (Byra, Parchomiuk, 2009).

The issue of adaptation to the university is cognitively interesting but also very important when we take into consideration social point of view including economical. Every year in Poland several hundred thousands young people starts their education at the university.

Having regard to the research results from the area of human resource management it is worth to say that the process of adaptation takes place in professional and also social dimension (Listwan, 2010). 
In view of university this process pertain to accommodate to the new organisational and didactic requirements. From the other side it also affects building new interpersonal relations in another social environment - with lecturers, administration workers, friends.

When we search for the factor that determine adaptation to new work/education requirements we need to pay attention to three variables: personality feature and student attitude also the effort that is taken in adaptation process by university in favor of first year students (Król, Ludwiczyński, 2006).

Important role of personality variables in the process of adaptation to higher education studies was showed and described in many researches (Buyukgoze-Kavas 2016; Lidy, Kahn 2006; Martin et al. 2011; Tomela 2008).

Due to leading subjects of researches the following personal variables will be broadly elaborated: life satisfaction, self-assessment, emotional intelligence and social competences. Subjective life satisfaction is the quality of life. All units make rate and evaluate different spheres of their life but also they do a rate of cognitive estimates of life as a one piece (Heszen, Sęk, 2007).

People who have higher level of life quality are more optimistic and better deal with social situations. What is more, they can effectively function in stress situations. In didactic sphere those people ale more intellectually arrange and less often show negative emotions, they are less prone to depression ( Gilman, Hubner, 2006; Lewis, Hubner, Malone et al. 2011; Proctor, Lindley, Malty, 2009).

Self-assessment show what people think about themselves and how do they rate their worth and effectiveness (Carr 2009). This rate is relatively permanent High level of unit's self-assessment is an important correlate of life (Diener, Diener, 1995) quality but also success at work.

People who reveal high level of self-assessment know and accept their strong and weak points. They are oriented toward compromise. In addition, they are looking for positive aspects in themselves and in different people but at the same time they are not afraid of any judgment. Baumeister and Leary (2000) show that self-assessment may be peculiar measure of our social status.

Emotional intelligence is an ability to use emotions in effective dealing with taskoriented and social situations (Salovey, Mayer, 1990).

According to D.Golemana (1997) emotional intelligence and connected with socialemotional competences are one of the main and most important source of life's successes. Person who is emotional intelligent has a deep self-consciousness, knows and understands their emotions and can lead them. This kind of person is also empathetic, motivated, full of respect to other people and take care of them.

Important element of people functioning as a social being is possession of social skills. Social competences condition efficiency functioning in different social situations and it may be get during social training (Matczak, 2006). 
People who have high level of social competences are assertive and willing to cooperate. Those people gladly help and support others. What is more, they appreciate other people company and they are life and soul of the party. They take care of others needs and are characterized by social resourcefulness.

The aim of researches was to define the meaning of personality variables in optimization of adaptation process to young people study who have just started studies at Academies.

Research questions:

1. What is the level of adaptation of students who have just started their studies?

2. What is the level of life quality, emotional intelligence, self-assessment and social competences of students who have just started their studies?

3. Are there any differences in adaptation level which are conditioned by personality of students who have just started studies?

Researches hypothesis: High level of life quality, emotional intelligence, selfassessment and social competences determine full level of adaptation to higher education universities requirements.

The researches were run at Lomza State University of Applied Science in Poland. 313 students of the 1st year took part in the research. They were students of 12 fields of studies. In the researches surveys with 24 questions were used. Thanks to that 3 levels of adaptation were defined- weak, partly and full. Personalities variables were describes by using 4 psychological questionnaires which enable to define the following levels:

1. satisfaction of life (SWLS by E. Diener, R. A. Emmons, R. J. Larson, S. Griffin);

2. self-assessment (SES by M.Rosenberg);

3. emotional intelligence (PKIE by A.Jaworowska, A.Matczak).

In questionnaire of emotional intelligence /PKIE/ there are general result /PKIEgeneral/ and 4 subscales such as:

a) acceptation of own emotions /AKC/,

b) recognition and understanding of others people emotions /EMP/,

c) control of own emotions $/ \mathrm{KON} /$,

d) recognition and understanding of own emotions /ROZ/;

4. social expertise (PROKOS by A.Matczak, K.Martowska).

Questionairre contains general result of social competences /PROKOS-general/ 
and 5 subscales:

a) assertive competences $/ \mathrm{A} /$,

b) cooperative competences $/ \mathrm{K} /$,

c) outgoing competences $/ T /$,

d) social resourcefulness/Z/,

e) social skills $/ \mathrm{S} /$.

The Cronbach Ralpha reliability of scales were $\alpha=.81$ to $\alpha=.95$.

The data obtained from the scales were analysed by using the SPSS 21.0. In order to determine differences Kruskal-Wallis $\mathrm{H}$ Test using SPSS Statistics the grade, a oneway variance analysis (ANOVA) were used.

This research paper arose as a part of statutory researches projects BST4/IWF/11/2014 funded by polish Ministry of Science and Higher Education.

\section{Body of the article}

Researches revealed that more than a half of first year students $(64,86 \%)$ weakly acclimated to changes arise from starting studies (Fig.1.).

Those people made decision to continue education at the very last moment and very often by accident. The knowledge they gained in high school is insufficient in order to deal with higher education knowledge standards. Those people are not satisfied about studies field which they chose.

It is worth notice that the sex determines level of adaptation to higher education (studies) ( $\left.X^{2}=14,03 ; p<.001\right)$. Among women bigger disproportions in acclimatization to studies were noticed than among men.

Figure 1: Level of adaptation of first year students at the State Univeristy of Applied Science in Lomza

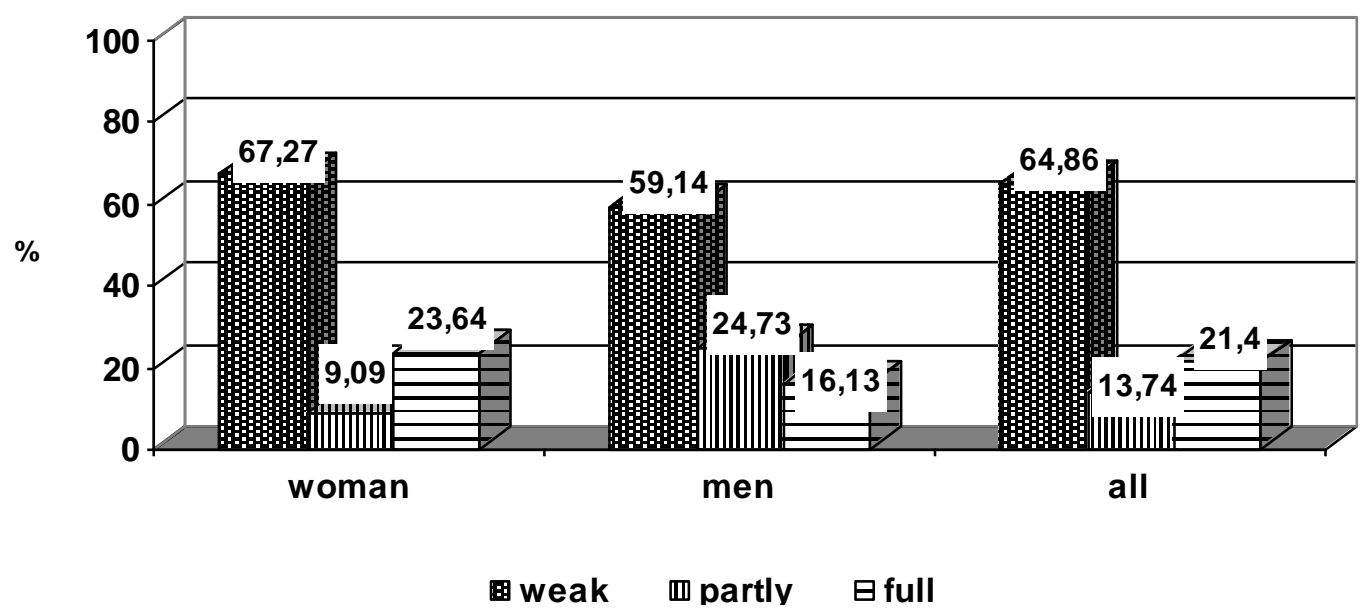


Every fifth person was fully adapt to new conditions connected with both- education process and social-economical factors such as change a place of living, new group of friends, weakening contact with family, new routine and life style.

At the same time every third of the first year women students cannot efficiently pull one selves together which is connected to new conditions reflected to the start of higher education $(67,27 \%)$.

Next parts of the paper will present characteristic of the level of selected personality variables among young people who are about to start studies (Fig.2., Fig.3.).

Researchers results show that $43,11 \%$ first year students evaluate their life satisfaction at very low level /SWLS/ (Fig.2.).

Figure 2: Satisfaction`s level of life /SWLS/ and self-assessment /SES/ of first year students at the State Univeristy of Applied Science in Lomza

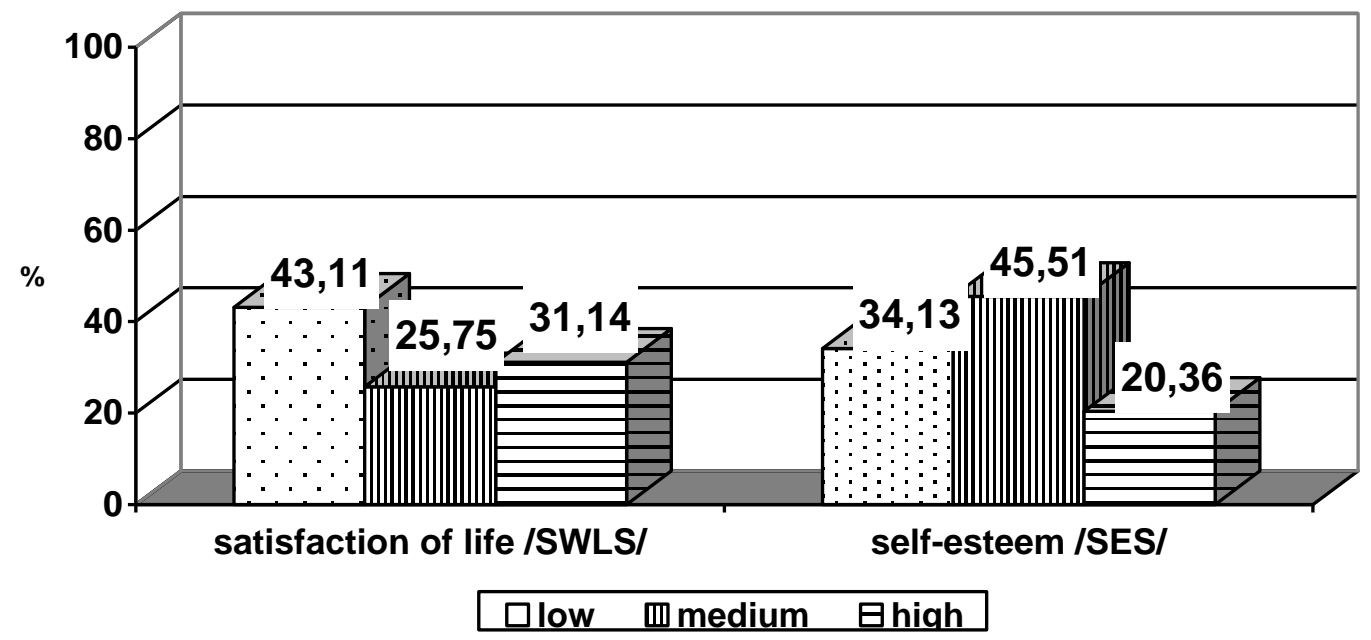

Those people rate their life conditions as bad and they are not happy about their achievement that they made so far.

Mentioned group of students claims that those life is far away from being perfect and they would like to start from the beginning again in order to make totally different decisions.

There are no differences in the level of satisfaction of life which are preconditioned by sex of people who were examined $(x 2=1,26 ; p<.532)$. Analization of the level of global self-assessment /SES/ it was revealed that almost half of interviewees characterize by its medium level. However, alarming fact is that every third examined person has low level of self-assessment $(45,51 \%)$. 
Those people do not believe in themselves, their self-esteem is low. What is more, they do not want to accept new challenges and take some actions. They also feel fear, negative emotions and are more prone to be depressed.

There are no differences in the level of global self-assessment which are conditioned by sex of people who were examined $\left(x^{2}=8,48 ; p<.075\right)$.

Young people who are about to start their studies in almost $80 \%$ are characterized with medium level of emotional intelligence /PKIE/ (Fig.3.).

Figure 3: Emotional's intelligence level /PKIE/ and social competences /PROKOS/ of first year student at the State Univeristy of Applied Science in Lomza

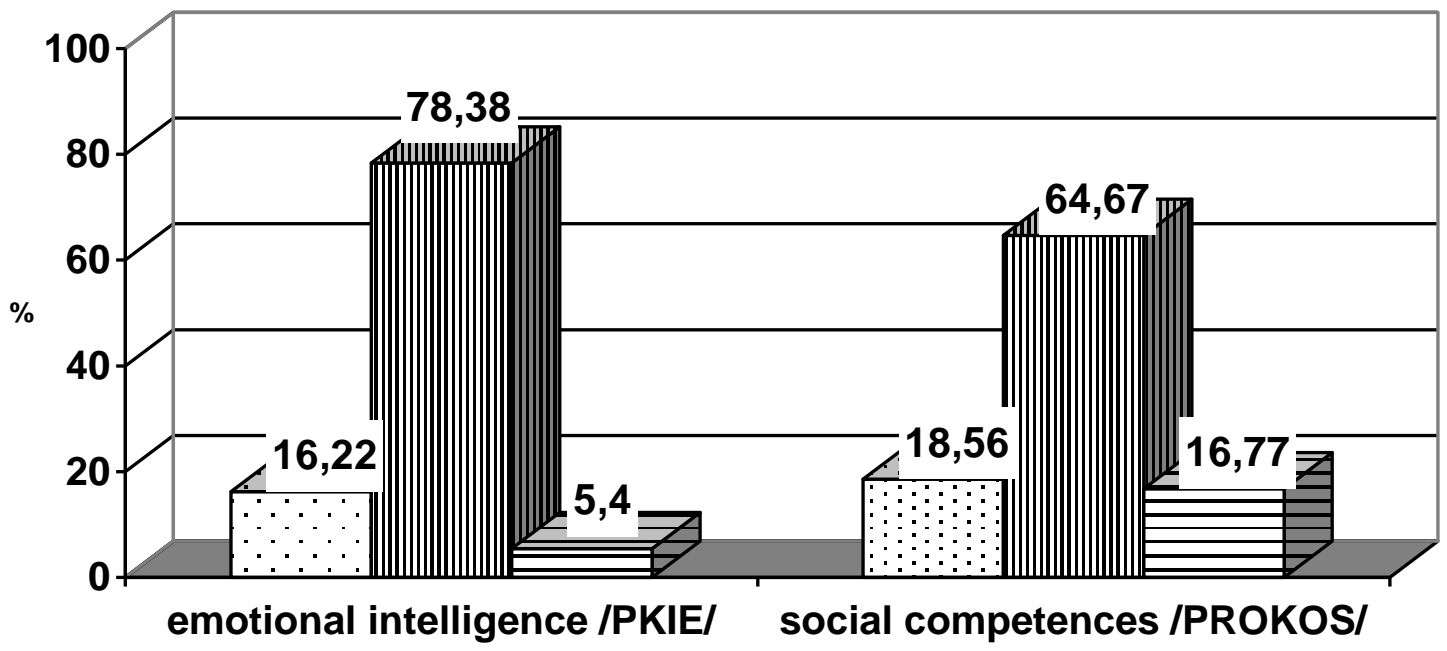

口low m medium Ehigh

Those people in average way will understand, accept and use their emotion in action. Not always they will be able to effectively control their emotions and be empathic.

There are no differences in the level of emotional intelligence which are conditioned by sex of people who were examined $\left(X^{2}=1,72 ; p<.190\right)$.

Emotional intelligence is connected with the level of education. Its medium level in majority number of students who will start their studies may be a good sign for the future

A positive aspect is the fact that $64,67 \%$ people who were interviewed revealed medium level of social competences /PROKOS/ (Fig.3.).Those people can be assertive but with various efficiency. The average level is the level on which they deal with situations which require: effecitve autopresentation, ability to wield influence on 
others, effective management, skills which will allow to phrase objection, talent to refuse.

Not always those people can cooperate in a harmonious way, take care of other people, help others or support them. The following features characterize this group of people: medium level of abilities of making new contacts and keeping old ones. When those people are in a group they averagely can present themselves as an interesting person. Described students are rather not socially resourceful in situations which require organizational and administrative actions.

Examined people very seldom arrange in civil actions and do something for others. They have problems with encourage others to do something for others. There are no differences in the social competences level which are conditioned by sex of people who took part in the researches $\left(x^{2}=2,51 ; p<.868\right)$.

Social competences shapes as a result of social training. So we can believe that next years of studies and starting some activities will contribute to the growth of its level.

In the next part of the paper the differences between the level of personality variables which characterize first year students with different level of adaptation to higher education studies (Tab.1.).

Table 1: Personality determinants in differences at the level of socialeducational adaptation of 1st year students at Lomza State University of Applied Science

\begin{tabular}{|c|c|c|c|c|c|c|c|c|c|}
\hline \multirow{3}{*}{ Variable } & \multicolumn{6}{|c|}{ Level of social-educational adaptation } & \multirow{2}{*}{\multicolumn{2}{|c|}{$\begin{array}{c}\text { Kruskal- } \\
\text { Wallis } \\
\text { test }\end{array}$}} & \multirow{3}{*}{$\begin{array}{l}\text { Depen- } \\
\text { dence }\end{array}$} \\
\hline & \multicolumn{2}{|c|}{$\begin{array}{c}\text { weak } \\
1 \\
\end{array}$} & \multicolumn{2}{|c|}{$\begin{array}{c}\text { partly } \\
2 \\
\end{array}$} & \multicolumn{2}{|c|}{$\begin{array}{c}\text { full } \\
3 \\
\end{array}$} & & & \\
\hline & $\bar{x}$ & SD & $\bar{x}$ & SD & $\bar{x}$ & SD & $\mathrm{H}$ & $\mathrm{p}$ & \\
\hline $\begin{array}{l}\text { satisfaction of life } \\
\text { /SWLS/ }\end{array}$ & 18,30 & 6,39 & 19,50 & 4,92 & 21,94 & 5,51 & 7,35 & $0,025^{*}$ & $2-3$ \\
\hline self- estrem /SES/ & 27,60 & 4,55 & 28,86 & 3,51 & 31,06 & 4,37 & 16,12 & $0,001^{*}$ & $3-1,2$ \\
\hline $\begin{array}{l}\text { emotional } \\
\text { intelligence } \\
\text { /PKIE -general/ }\end{array}$ & 311,22 & 6,1 & 315,99 & 30,57 & 329,40 & 41,07 & 2,40 & 0,302 & - \\
\hline $\begin{array}{l}\text { acceptation of } \\
\text { own emotions } \\
\text { /AKC/ }\end{array}$ & 48,33 & 7,44 & 49,91 & 8,21 & 53,26 & 8,47 & 4,72 & 0,095 & \\
\hline
\end{tabular}




\begin{tabular}{|c|c|c|c|c|c|c|c|c|c|}
\hline $\begin{array}{l}\text { empathy } \\
\text { /EMP/ }\end{array}$ & 67,78 & 7,89 & 66,12 & 8,37 & 66,17 & 11,11 & 0,56 & 0,757 & - \\
\hline $\begin{array}{l}\text { control of own } \\
\text { emotions } \\
\text { /KON/ }\end{array}$ & 29,33 & 5,74 & 30,30 & 5,78 & 32,74 & 9,32 & 1,24 & 0,537 & - \\
\hline $\begin{array}{l}\text { recognition and } \\
\text { understanding of } \\
\text { own emotions } \\
\text { /ROZ/ }\end{array}$ & 27,44 & 4,18 & 30,55 & 6,45 & 32,91 & 11,73 & 5,55 & 0,062 & - \\
\hline $\begin{array}{l}\text { social } \\
\text { competences } \\
\text { /PROKOS- } \\
\text { general/ }\end{array}$ & 162,55 & 18,9 & 173,76 & 23,87 & 182,44 & 24,99 & 9,62 & $0,008^{*}$ & $1-3$ \\
\hline $\begin{array}{l}\text { assertive } \\
\text { competences /A/ }\end{array}$ & 35,90 & 5,54 & 37,11 & 6,48 & 39,86 & 7,24 & 8,45 & $0,015^{\star}$ & $2-3$ \\
\hline $\begin{array}{l}\text { cooperative } \\
\text { competences //K/ }\end{array}$ & 47,85 & 5,04 & 50,02 & 6,95 & 50,58 & 6,29 & 3,24 & 0,198 & - \\
\hline $\begin{array}{l}\text { outgoing } \\
\text { competences /T/ }\end{array}$ & 27,95 & 5,26 & 30,63 & 5,88 & 33,86 & 6,00 & 12,48 & $0,002^{*}$ & $3-1,2$ \\
\hline $\begin{array}{l}\text { social } \\
\text { resourcefulness } \\
\text { /Z/ }\end{array}$ & 37,95 & 3,95 & 40,69 & 6,25 & 41,42 & 5,60 & 5,62 & 0,060 & - \\
\hline social skills /S/ & 14,80 & 2,26 & 16,28 & 3,31 & 17,19 & 3,13 & 7,28 & $0,026^{*}$ & $1-3$ \\
\hline
\end{tabular}

Level of 4 personality variables was analized in the researches: satisfaction of life /SWLS/, self- estrem /SES/, emotional intelligence /PKIE/ and social competences /PROKOS/.

In questionnaire of emotional intelligence /PKIE/ there are 4 subscales such as:

acceptation of own emotions /AKC/, recognition and understanding of others people emotions- empathy /EMP/, control of own emotions /KON/, recognition and understaning of own emotions /ROZ/ and general result /PKIE - general/.

In social competences profile /PROKOS/ there are 5 subscales: assertive competences $/ A /$, cooperative competences $/ K /$, outgoing competences $/ T /$, social resourcefulness/Z/, social resourcefulness /Z/ and general result /PROKOS general/.

Researches revealed that there are differences in the structure of personality of students who adapt weakly, partly or fully to social-educational constraints of higher education. 
Full step of study adaptation displays in making decision about choosing studies couple of years before those studies actually begin. They also have sufficient education background from the high school, good marks during 1st year of studies and high level of satisfaction with their studies.

Students who achieved full level of adaptation to higher education studies were characterized by higher level of satisfaction of life $(H=7,35 ; p<.025)$. In comparison, with students who adapt partly they were happier about their previous successes, life conditions, fulfilling ideals. What is more, they still wanted to follow their path without introducing any changes.

Depending on the level of adaptation to studies there are differences at the level of global self-assessments of the 1st year students $(H=16,12 ; p<.001)$. Students who can fully adapt to studies have higher level of global self-assessment. Their high feeling of self-regard displays in a positive rating of themselves, skills and abilities of recognition their strong and weak points and accept them.

Those people also positive rate other people other people actions but they do not aim at be perfect in every sphere of life. In addition, they can solve conflicts in an effective way.

Level of social competences among young people who are about to start their studies will be different because the level of their adaptation to social-eduactional universities requirements. Students who fully adapt to requirements of higher education schools reveal the highest level of social competences $(H=9,62 ; p<.008)$.

Students who adapt to new social-adaptive requirements are different from students who adapt partly or weakly. This difference is the level of competences: assertive competences $(H=8,45 p<.015)$, outgoing competences $(H=12,48 ; p<.002)$ and civil competences $(H=7,28 ; p<.026)$.

People who adapt to the University requirements in fully way are assertive, they respect themselves and other people. In social situations they can draw a line and manage them in an effective way. Very often they are in the centre of all events, they are easy going, they like other people and stay in touch with them, they are happy and they have good mood. Those people are willing to take some actions for other people, they see their needs, take part in social actions and work for others goodness. Research results which were presented above showed differences in personalities structures of students who adapt to their studies with various efficiency.

\section{Conclusions}

Researches results confirm researches hypothesis. Personality's common determinant acclimatization to studies of 1st year students. The level of emotional balance is a base to psycho-social adaptation shape for requirements of higher education universities (Lidy, Kahn 2006). 50\% of students reveal low level of 
adaptation to studies and at the same time they need to shape and develop their emotional and motivation sphere (Serebryakova et al. 2016).

Researches confirmed that high level of adaptation to studies is connected with high level of self-assessment and life satisfaction which is close to results of researches which were made by other authors (Martin et al. 2008, Martin et al. 2013, Toomela 2008).

1. The fully social- educational adaptation of 1 st year students foster high level of life quality, self-assessment, social expertise (mainly: assertiveness, conviviality, social activist).

2. Academy should actively support students who start their studies by organising during the 1st semester additional adaptation workshops and inspire people and students to social actions which help to be a part of local society life.

Personality is relevant in our whole life. Young people who are characterized by bigger resilient, hope and optimism are at the same time more likely to perceive themselves as more adaptable in their careers and future life (Buyukoze-Kavas 2016).

\section{Reference}

BAUMEISTER, R.F. and LEARY, M.R. (2000) The Nature and Function of Self-Esteem:

Sociometer Theory. Advances in Experimental Social Psychology. Vol. 32, p.1-62.

BUYUKGOZE-KAVAS, A. (2016) Predicting Career Adaptability from Positive Psychological Traits.

Career Develoment Quarterly,Vo.I. 64, No.2, p.114-125.

BYRA, S. and PARCHOMIUK, M. (2009) Osobowościowe i Społeczne Uwarunkowania Radzenia

Sobie ze Stresem przez Studentów Pierwszego Roku. Wydawnictwo UMCS: Lublin.

CARR, A.(2009) Psychologia Pozytywna. Nauka o Szczęściu i Ludzkich Siłach.

Poznań: Zysk i S-ka.

DIENER, E. and DIENER, M. (1995) Cross-Cultural Correlates of Life Satisfaction and Self-Esteem. Journal of Personality and Social Psychology, Vol. 68(4), p.653-663.

GILMAN, R. and HUEBNER, E.S. (2006) Characteristics of Adolescents Who Report Very High Life Satisfaction. Journal of Youth and Adolescence, Vol. 35, No.3, p. 293-301.

GOLEMAN, D. (1997) Inteligencja Emocjonalna. Media Rodzina Wydawnictwo: Poznań.

HESZEN, I. and SĘK, H. (2012) Psychologia Zdrowia. PWN: Warszawa. 
ISKRA, J. (2011) Wybrane Uwarunkowania Trudności Doświadczanych przez Studentów Pierwszego Roku. IMPULS: Kraków.

KRÓL, H. and LUDWICZYŃSKI, A. (2006) Zarządzanie Zasobami Ludzkimi. Tworzenie Kapitału Ludzkiego Organizacji. PWN: Warszawa.

LEWIS, A.D., HUEBNER, E.S., MALONE, P.S. and VALOIS, R.F. (2011) Life Satisfaction and Student Engagement in Adolescents. Journal of Youth and Adolescence, Vol.40, No.3, p.246-262.

LIDY, K.M. and KAHN, J.H. (2006) Personality as Predictor of First-Semester Adjustment to College: The Mediational Role of Perceived Social Support

LISTWAN T. (red.) (2010) Zarządzanie Kadrami. C.H.Beck: Warszawa.

MARTIN, A.J. ; NEJAD, H.: COLMAR, S. and LIEM, G., A. D. (2012) Adaptability: Conceptual and Empirical Perspectives on Responses to Change, Novelty and Uncertainty. Australian Journal of Guidance and Counselling 2012, Vol. 22, No1, p. 58-81.

MARTIN, A.J. ; NEJAD, H.: COLMAR, S. and LIEM, G., A. D. (2013) Adaptability: How Students` Responses to Uncertainty and Novelty Predict Their Academic and Non-Academic Outcomes. Journal Education Psychology, Vol.105, No.3, p. 728-746.

MATCZAK A. (2006) Natura i Struktura Inteligencji Emocjonalnej. Psychologia, Etologia, Genetyka, No.13, p.59-87.

SALOVEY,P. and MAYER, J.D. (1990) Emotional Intelligence. Immagination, Cognition and Personality, Vol.9, p.185-211.

SEREBRYAKOVA, T.,MOROZOVA, L.,KOCHNEVA, E.M.,ZHAROVA, D.V., KOSTYLEVA, E.A. and KOLARKOVA, O.G. (2016) Emotional Stability as a Condition of Students Adaptation to Studying in a Higher Educational Institution. International Journal of Environmental and Science Education, Vol. 11, No.15, p.7486-7494.

TOOMELA, A. (2008) Noncognitive Correlates of Education. Learning \& Individual Differences. Vol.18, No.1, p.19-28. 